\title{
Lymphoepithelioma-like carcinoma of the skin
}

\author{
Daniel A Peters MD ${ }^{1}$, J Frederick Watkins MD FRCSC ${ }^{2}$, lain D Young MD CM FRCPC ${ }^{2}$
}

DA Peters, JF Watkins, ID Young. Lymphoepithelioma-like carcinoma of the skin. Can J Plast Surg 2002;10(5):220-222.

Lymphoepithelioma-like carcinoma of the skin is a very rare malignancy of undetermined histogenesis that typically presents as a firm, slowly enlarging, nonulcerated, nonpigmented cutaneous nodule on the face and scalp of older individuals. Despite having histological features of an anaplastic large cell carcinoma, this tumour follows an indolent course and complete excision is usually curative. A case of lymphoepithelioma-like carcinoma of the skin on the arm of a 38-year-old white woman is presented and the literature on this rare skin malignancy is reviewed.

Key Words: Lymphoepithelioma-like carcinoma of the skin

\section{Carcinome de la peau de type lympho- épithélial}

Le carcinome de la peau de type lympho-épithélial est une tumeur très rare dont l'histogenèse reste encore inconnue et qui se manifeste la plupart du temps par des nodules cutanés, fermes, non ulcérés, non pigmentés, à progression lente sur la face et le cuir chevelu de personnes âgées. Malgré ses caractéristiques histologiques de carcinome à grandes cellules anaplasiques, la tumeur suit une évolution torpide et son excision complète suffit généralement à la guérison. Voici un cas de carcinome de la peau de type lympho-épithélial sur un bras, chez une femme de 38 ans, de race blanche. Suit un examen de la documentation sur cette rare tumeur maligne de la peau.
The term 'lymphoepithelioma' usually refers to a tumour of the nasopharynx in which large anaplastic carcinoma cells are associated closely with lymphocytes (1). Tumours with similar histological patterns have been documented in the uterine cervix (2), salivary gland (3), thymus and larynx (4). They have also been found in the skin, where they are termed 'lymphoepithelioma-like carcinoma of the skin' (5-23). This skin tumour usually presents on the face and scalp of middle-aged and elderly people $(5,8,13)$. The histogenesis of the tumour is unclear, with some cases showing no differentiation (5) and others showing adnexal differentiation $(8,12)$. The present report summarizes a case of a 38-year-old woman with lymphoepithelioma-like carci- noma of the skin on the left arm and reviews the clinical and pathological features of this rare neoplasm.

\section{CASE PRESENTATION}

An otherwise healthy 38-year-old white woman was referred to dermatology regarding a slowly enlarging, firm dermal nodule on the lateral aspect of her left arm measuring approximately $2.0 \times 1.5 \mathrm{~cm}$. This lesion had been present for two years. It was not pigmented and the clinical appearance was most suggestive of a dermatofibrosarcoma protuberans. The remainder of the skin examination was unremarkable. There was no axillary lymphadenopathy. A punch biopsy was performed and a pathological diagnosis of

\footnotetext{
${ }^{1}$ Plastic Surgery, University of British Columbia, Vancouver, British Columbia; ${ }^{2}$ Division of Plastic Surgery, Department of Surgery and Department of Pathology, Queen's University, Kingston, Ontario 

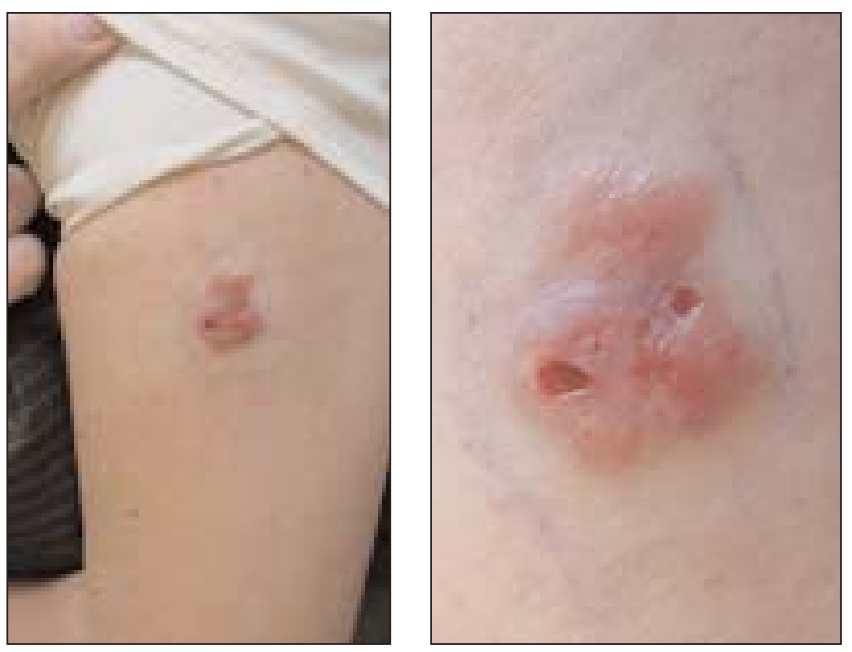

Figure 1) Lymphoepithelioma-like carcinoma of the skin on the upper arm of a 38-year-old woman just before excisional biopsy. The ulcerations represent punch biopsies

a large cell carcinoma was made. There was some question as to whether this lesion represented a primary neoplasm or a secondary metastasis. The patient was referred to the plastic surgery clinic for complete excision. A narrow margin excisional biopsy was carried out under local anesthesia and the entire lesion was sent for pathological review (Figure 1).

Histological examination demonstrated a malignant epithelial tumour measuring $13 \mathrm{~mm}$ in greatest dimension that spanned the dermis and extended along a pushing margin into superficial adipose tissue. The tumour was focally contiguous with the epidermis and was composed predominantly of monotomous, cohesive sheets of large polygonal cells that exhibited neither squamous nor acinar differentiation. Tumour cell nuclei demonstrated high grade atypia, the mitotic rate was high and foci of necrosis were apparent. A light diffuse infiltrate of lymphocytes was present within the tumour (Figure 2). Immunohistochemistry showed that the tumour cells were diffusely and strongly positive for high and low molecular weight cytokeratins, including cytokeratin 7 , and focally expressed epithelial membrane antigen. The tumour did not express cytokeratin 20, S-100 protein, HMB-45, carcinoembryonic antigen, neuron specific enolase, chromogranin, CD34 or vimentin.

Due to concern that this lesion may have been a metastasis, a search for an occult primary tumour was conducted. This included chest $\mathrm{x}$-ray, complete physical examination and indirect nasolaryngoscopy. No primary tumour was identified. The diagnosis of lymphoepithelioma-like carcinoma of the skin was made on the basis of the combination of the histological features of the neoplasm, its immunophenotype, its apparent origin from the epidermis, its indolent clinical course and the absence of evidence to suggest that the tumour could be a metastasis from a primary site. Wide local excision was performed with a $1 \mathrm{~cm}$ margin. The patient was referred to the Kingston Regional Cancer Centre for assessment and no further treatment was

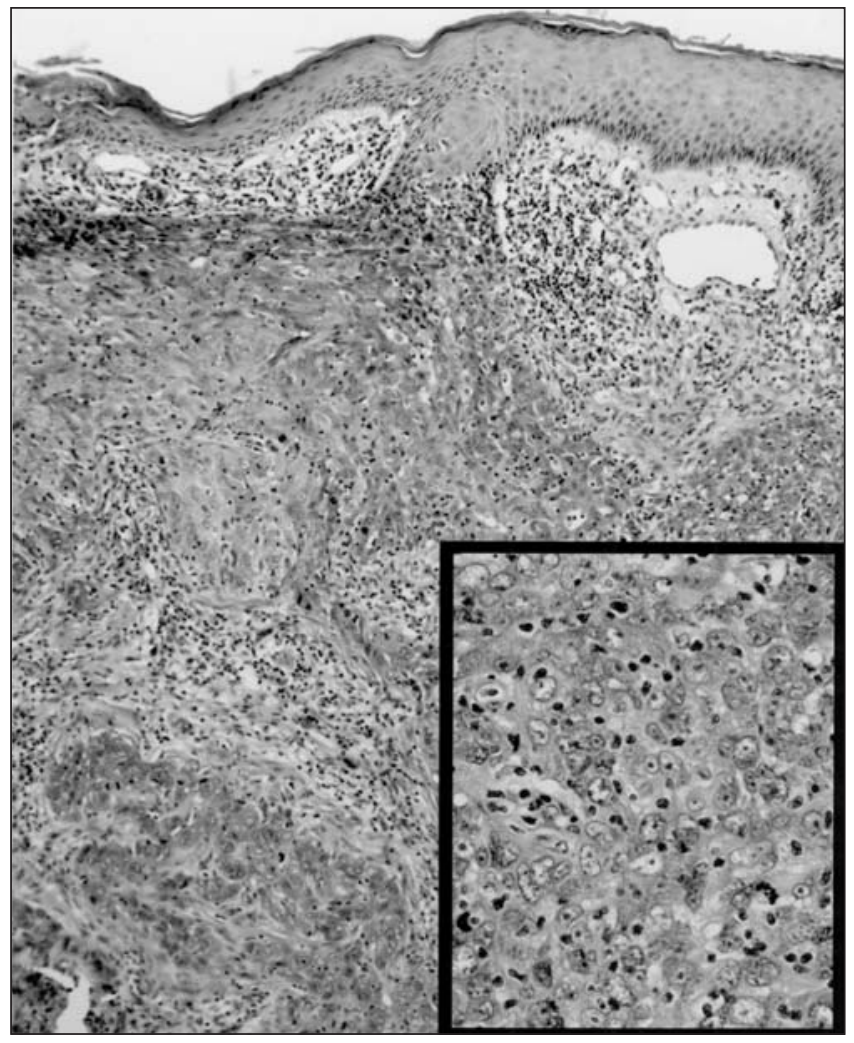

Figure 2) An invasive carcinoma originates from the epidermis and penetrates deeply into the dermis. The carcinoma is comprised of large undifferentiated cells that are associated with a prominent lymphoid infiltrate. Hematoxyline-phyloxin-saffron stain (original magnification $\times 800$ )

planned. Long term follow-up is provided by the Department of Dermatology.

\section{DISCUSSION}

In 1988, Swanson et al (5) reported the first five cases of lymphoepithelioma-like carcinoma of the skin. The present report is the thirty-seventh case of this rare neoplasm. It usually presents on the face or scalp of individuals ranging in age from 50 to 91 years as a slow growing, nonpigmented nodule of less than $3 \mathrm{~cm}$ in size. These lesions are usually present for six months to 12 years at the time of diagnosis $(5-21,23,24)$. The tumour is rarely ulcerated $(19,20)$ and is usually asymptomatic $(5-18,23)$. The clinical course is almost always indolent, although there have been rare reports of nodal metastases at the time of diagnosis and one fatality from metastatic disease $(5,15)$. The present case is only the second reported occurrence of this lesion outside the head and neck (5) and only the second case reported in a person under the age of fifty years (22).

The rarity of this lesion represents a diagnostic challenge. The clinical differential diagnosis is extensive and includes metastatic carcinoma, dermatofibrosarcoma protuberans, vascular tumours, granulomatous lesions and basal cell carcinoma. Pathologically, the lesion appears far more aggressive than the appearance, rate of growth and clinical course would suggest. This lesion may be misdiagnosed as 
metastastic carcinoma, particularly from the nasopharynx, prompting unnecessary invasive and extensive investigations. It has also been misdiagnosed as a lymphoproliferative disorder. Accurate pathological diagnosis is aided by a thorough history, but rests on a combination of histology, immunohistochemistry and, less often, Epstein-Barr virus (EBV) in situ hybridization (ISH) and electron microscopy (24-26).

The role of EBV in nasopharyngeal lymphoepithelioma has been documented (9). Several studies using ISH have suggested that EBV is not a factor in lymphoepitheliomalike carcinoma of the skin $(8,16,23,27,29,30)$.

In 35 of 37 reported cases, the clinical course has been indolent. There has been one reported fatality in which the tumour was initially misdiagnosed as a lymphoproliferative disorder (5). There is one reported case of presentation with metastasis to a local lymph node where nodal dissection and adjuvant radiotherapy were curative at six years' follow-up (15). There is also a case in which the lesion was not resectable. Radiotherapy was administered and the

\section{REFERENCES}

1. Michaels L. Squamous carcinoma in the nasal part of the pharynx. In: Hinchcliffe R, Harrison D, eds. Foundations of Otolaryngology. London: William Heinemann Medical Books Ltd, 1976:696-8.

2. Mills SE, Austin MB, Randall ME. Lymphoepithelioma-like carcinoma of the uterine cervix. Am J Surg Pathol 1985;9:883-9.

3. Bosch JD, Kudryk WH, Johnson GH. The malignant lymphoepithelial lesion of the salivary glands. J Otolaryngol 1988; 17:187-90.

4. Wick MR, Scheithaur BW, Weiland LH, Bernatz PE. Primary thymic carcinomas. Am J Surg Pathol 1982;6:613-30.

5. Swanson SA, Cooper PH, Mills SE, Wick MR. Lymphoepitheliomalike carcinoma of the skin. Mod Pathol 1988;1:359-65.

6. Walker AN, Kent D, Mitchell AR. Lymphoepithelioma-like carcinoma in the skin. J Am Acad Dermatol 1990;22:691-3.

7. Malhotra R, Woda B, Bhawan J. Lymphoepithelial-like carcinoma of the skin: The microscopic and immunohistochemical findings of two patients. J Cutan Pathol 1989:16:317. (Abst)

8. Wick MR, Swanson PE, LeBoit PE, Strickler JG, Cooper PH. Lymphoepithelioma-like carcinoma of the skin with adnexal differentiation. J Cutan Pathol 1991;18:93-102.

9. Kutzner H, Schwenzer G, Embacher B, Kutzner U, Schroder J. Lymphoepithelioma-like carcinoma of the skin. Hautarzt 1991;42:575-9

10. Carr KA, Bulengo S, Weiss LM, Nickoloff BJ. Lymphoepitheliomalike carcinoma of the skin: A case report with immunophenotypic analysis and in situ hybridization for Epstein-Barr viral genome. Am J Surg Pathol 1992;16:903.

11. Ortiz-Frutos FJ, Zarco C, Gil R, Ballestin C, Iglesias L. Lymphoepithelioma-like carcinoma of the skin. Clin Exp Dermatol 1993;18:83-6.

12. Requena L, Sanchez Yus E, Jiminez E, Roo E. Lymphoepitheliomalike carcinoma of the skin: A light-microscopic and immunohistochemical study. J Cutan Pathol 1994;21:541-8.

13. Maruyama M, Miyauchi S, Ohtsuka H, Miki Y. Lymphoepitheliomalike carcinoma originating on the eyelid. J Dermatol 1995;22:218-22

14. Sthar BJ. Lymphoepithelioma-like carcinoma of the skin. J Cutan Pathol 1993;20:518-9.

15. Takayasu S, Yoshiyama M, Kurata S, Terashi H. Lymphoepitheliomalike carcinoma of the skin. J Dermatol 1996;23:472-5.

16. Shek TW, Leung EY, Luk IS, et al. Lymphoepithelioma-like carcinoma of the skin. Am J Dermatopathol 1996;18:637-44. patient was disease free at two years' follow-up (11). In a case of local recurrence, radiotherapy was employed and the patient was clinically disease free at 18 months' follow-up (6). The case reports to date appear to indicate that wide local excision is appropriate definitive treatment and that radiotherapy may be helpful if complete surgical excision is not possible or if the lesion has spread to the regional lymph nodes. Mohs micrographic surgery is an acceptable alternative if tissue preservation is imperative $(26,28)$.

Lymphoepithelioma-like carcinoma of the skin presents as a slow growing, nonpigmented nodule with similar clinical appearance to dermatofibrosarcoma protuberans. Microscopically, it can be confused with an aggressive metastatic carcinoma. The diagnosis is established on the basis of the indolent clinical course, the clinical exclusion of occult primary lesions and by careful pathological examination. Wide local excision should be curative.

ACKNOWLEDGEMENTS: The authors thank Drs John Davidson and John Blakeman for their contributions to this report.

17. Ko T, Muramatsu T, Shirai T. Lymphoepithelioma-like carcinoma of the skin. J Dermatol 1997;24:104-9.

18. Dudley CM, Snow SN, Voyovich MC, Warner TF, Hartig GK. Enlarging facial nodule on an elderly patient: Lymphoepitheliomalike carcinoma of the skin. Arch Dermatol 1998;134:1628-9.

19. Lind AC, Breer WA, Wick MR. Lymphoepithelioma-like carcinoma of the skin with apparent origin in the epidermis-a pattern or an entity? A case report. Cancer 1999;85:884-90.

20. Bornhovd EC, Schmid-Wendtner MH, Volkenandt M, Wendtner CM, Sander CA. Malignant skin lesions. Case 2: Lymphoepithelioma-like carcinoma of the skin. J Clin Oncol 1999; 17:3853-5.

21. Chen KT. Cytology of lymphoepithelioma-like carcinoma of the skin. Diagn Cytopathol 1999;21:230-2.

22. Ping HE, Dugan E. Lymphoepithelioma-like carcinoma of the skin occurring in a 34-year old Jamaican woman. J Cutan Pathol 1999;26:460-1.

23. Ferlicot S, Plantier F, Rethers L, Bui AD, Wechsler J. Lymphoepithelioma-like carcinoma of the skin: a report of 3 Epstein Barr virus (EBV)-negative additional cases. Immunohistochemical study of the stroma reaction. J Cutan Pathol 2000;27:306-11.

24. Okamura JM, Barr RJ. Cutaneous lymphoepithelial neoplasms. Adv Dermatol 1997;12:277-94.

25. Petter G, Haustein UF. Histologic subtyping and malignancy assessment of cutaneous squamous cell carcinoma. Dermatol Surg 2000;26:521-30.

26. Robins P, Perez MI. Lymphoepithelioma-like carcinoma of the skin treated by Mohs micrographic surgery. J Am Acad Dermatol 1995;32:814-6.

27. Dozier SE, Jones TR, Nelson-Adesokan P, Hruza GJ. Lymphoepithelioma-like carcinoma of the skin treated with Mohs micrographic surgery. Dermatol Surg 1995;21:690-4.

28. Jimenez F, Clark RE, Buchanan MD, Kamino H. Lympoepitheliomalike carcinoma of the skin treated with Mohs micrographic surgery in combination with immune staining for cytokeratins. J Am Acad Dermatol 1995;32:878-81.

29. Iezzoni JC, Gaffey MJ, Weiss LM. The role of Epstein-Barr virus in lymphoepithelioma-like carcinomas. Am J Clin Pathol 1995;103:308-15.

30. Leung EY, Yik YH, Chan JK. Lack of demonstrable EBV in Asian lymphoepithelioma-like carcinoma of the skin. Am J Surg Pathol 1995;19:974-6. 